\title{
Balanced conditions or slight mass gain of glaciers in the Lahaul and Spiti region (northern India, Himalaya) during the nineties preceded recent mass loss
}

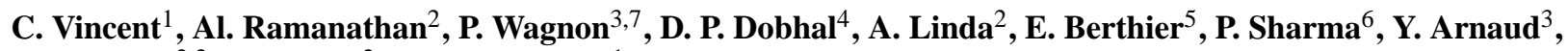 \\ M. F. Azam ${ }^{2,3}$, P. G. Jose ${ }^{2}$, and J. Gardelle ${ }^{1}$ \\ ${ }^{1}$ UJF - Grenoble1 / CNRS, Laboratoire de Glaciologie et Géophysique de 1' Environnement (LGGE) UMR 5183, \\ Grenoble, 38041, France \\ ${ }^{2}$ School of Environmental Sciences, Jawaharlal Nehru University, New Delhi 110067, India \\ ${ }^{3}$ IRD / UJF - Grenoble 1 / CNRS / G-INP, LGGE UMR 5183, LTHE UMR 5564, Grenoble, 38402, France \\ ${ }^{4}$ Wadia Institute of Himalayan Geology, Dehra Dun 248 001, India \\ ${ }^{5}$ CNRS, Université de Toulouse, LEGOS, 14 av. Ed. Belin Toulouse 31400 France \\ ${ }^{6}$ National Centre for Antarctic and Ocean Research, Headland Sada, Goa 403804, India \\ ${ }^{7}$ ICIMOD, GPO Box 3226, Kathmandu, Nepal \\ Correspondence to: C. Vincent (christian.vincent@ujf-grenoble.fr)
}

Received: 24 July 2012 - Published in The Cryosphere Discuss.: 5 September 2012

Revised: 28 February 2013 - Accepted: 7 March 2013 - Published: 3 April 2013

\begin{abstract}
The volume change of the Chhota Shigri Glacier (India, $32^{\circ} 20 \mathrm{~N}, 77^{\circ} 30^{\prime} \mathrm{E}$ ) between 1988 and 2010 has been determined using in situ geodetic measurements. This glacier has experienced only a slight mass loss between 1988 and $2010(-3.8 \pm 2.0 \mathrm{~m}$ w.e. (water equivalent) corresponding to $-0.17 \mathrm{pm} 0.09 \mathrm{mw}$.e. $\left.\mathrm{yr}^{-1}\right)$. Using satellite digital elevation models (DEM) differencing and field measurements, we measure a negative mass balance (MB) between 1999 and $2010 \quad(-4.8 \pm 1.8 \mathrm{mw}$.e. corresponding to $-0.44 \pm 0.16 \mathrm{mw}$.e. $\left.\mathrm{yr}^{-1}\right)$. Thus, we deduce a slightly positive or near-zero MB between 1988 and $1999(+1.0 \pm 2.7 \mathrm{~m}$ w.e. corresponding to $+0.09 \pm 0.24 \mathrm{~m}$ w.e. $\left.\mathrm{yr}^{-1}\right)$. Furthermore, satellite DEM differencing reveals that the $\mathrm{MB}$ of the Chhota Shigri Glacier $\left(-0.39 \mathrm{pm} 0.15 \mathrm{~m}\right.$ w.e. $\left.\mathrm{yr}^{-1}\right)$ has been only slightly less negative than the $\mathrm{MB}$ of a $2110 \mathrm{~km}^{2}$ glaciarized area in the Lahaul and Spiti region $\left(-0.44 \pm 0.09\right.$ mw.e. $\left.\mathrm{yr}^{-1}\right)$ during 1999-2011. Hence, we conclude that the ice wastage is probably moderate in this region over the last $22 \mathrm{yr}$, with near equilibrium conditions during the nineties, and an ice mass loss after. The turning point from balanced to negative mass budget is not known but lies probably in the late nineties and at the latest in 1999. This positive or near-zero
\end{abstract}

MB for Chhota Shigri Glacier (and probably for the surrounding glaciers of the Lahaul and Spiti region) during at least part of the 1990s contrasts with a recent compilation of MB data in the Himalayan range that indicated ice wastage since 1975. However, in agreement with this compilation, we confirm more negative balances since the beginning of the 21 st century.

\section{Introduction}

Glaciers have been recognized as good climatic indicators (e.g. Oerlemans, 2001), especially in high remote areas such as the Himalayas where meteorological observations are difficult and, thus, only recent and sparse (e.g. Shekhar et al., 2010). Moreover, understanding the evolution of Himalayan glaciers is of great interest for diagnosing the future water availability in these highly populated watersheds (Kaser et al., 2010; Immerzeel et al., 2010; Thayyen and Gergan, 2010). Unfortunately, data on recent glacier changes are sparse and even sparser as we go back in time (Cogley, 2011; Bolch et al., 2012) and, thus, the rate at which these glaciers are changing remains poorly constrained. Most field 
measurements in the Himalayas over recent decades concern changes in glacier length or area for a limited number of glaciers (e.g. Dyurgerov and Meier, 2005; Cogley, 2009, 2011; Kargel et al., 2011; WGMS, 2011). Remote sensing provides regional data for numerous glaciers over the last 3 decades, but these data are also mostly limited to glacier length/area variations (e.g. Scherler et al., 2011; Bhambri et al., 2011). However, these length and area variations cannot be directly interpreted as direct indicators of climate change on an annual or decadal timescale due to the lag in the response time of glaciers (Cuffey and Paterson, 2010) and because most of these glaciers are partly covered by debris that strongly affects the relationship between the surface energy balance and melting (Fujita and Nuimura, 2011). Moreover, snout fluctuations obtained from satellite or aerial images are subject to uncertainty due to difficulties in delineating debris-covered glacier tongues, which are not easily identifiable on images. For these reasons, glacier trends obtained from snout fluctuations alone in the Himalayas provide only a partial picture of glacier variability (Raina, 2009). The best indicator of climate change is the glacier-wide mass balance (MB) which results mainly from climate variables such as solid precipitation and heat and radiative fluxes via ablation (Oerlemans, 2001) provided that the MB is measured on a surface free of debris.

The MB can be obtained directly using the geodetic method (elevation changes measured over the whole glacier area) or the glaciological method (Cuffey and Paterson, 2010). Recent studies (Berthier et al., 2007; Bolch et al., 2011; Gardelle et al., 2012a; Nuimura et al., 2012) provide volumetric MB for numerous glaciers in the Himalayas using digital elevation models (DEM) derived from spaceborne sensors, but generally with larger uncertainties than those obtained using in situ measurements when a single small to medium-size glacier is considered. Satellite laser altimetry provides accurate measurements of elevation changes along the whole mountain range but the sampling is sparse and restricted to the 2003-2009 time interval (Kääb et al., 2012). Moreover, very few continuous MB observations using the glaciological method are available in the Himalayas (Dyurgerov and Meier, 2005; Cogley, 2009, 2011). Figure 1 shows the locations of these surveyed glaciers in the western Himalaya, a region which includes roughly one third of all Himalayan glaciers, representing a total ice-covered area of ca. $9000 \mathrm{~km}^{2}$ (Bolch et al., 2012). The $700 \mathrm{~km}$ long western Himalaya includes all glaciers of northern India between Pakistan and Nepal, including the ridge north of the Indus River (Bolch et al., 2012). The MB series obtained by the glaciological method in this region are listed in Table 1.

One of the longest continuous series, initiated only since 2002, comes from Chhota Shigri Glacier in India (Wagnon et al., 2007; Azam et al., 2012). In this paper, we extend the Chhota Shigri MB back to 1988 using in situ geodetic measurements performed in 1988 and 2010. In addition, we assess whether the Chhota Shigri Glacier is representa-

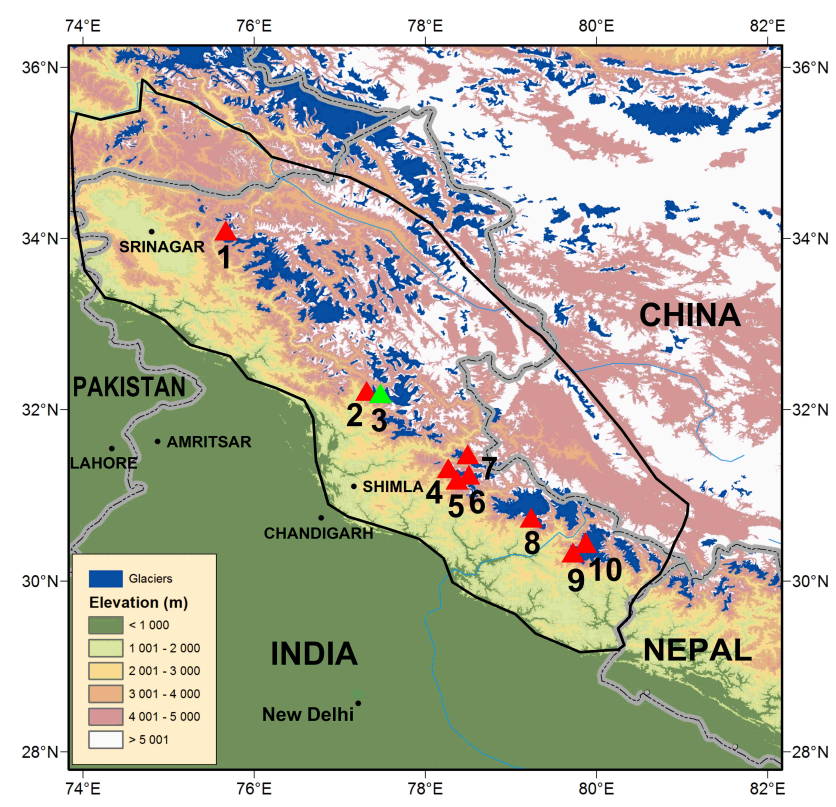

Fig. 1. Map of the western Himalayan glaciers with MB series longer than 1 yr. Details on each glacier (triangles) can be found in Table 1 with the corresponding numbers. Chhota Shigri Glacier has number 3 (green triangle). The boundary of western Himalaya as defined in Bolch et al. (2012) is also reported. Political boundaries are tentative only.

tive of the whole Lahaul and Spiti region using ice elevation changes measured between 1999 and 2011 from DEMs derived from spaceborne sensors. Finally, we compile the glaciological MB available from other glaciers during recent decades to put the $22 \mathrm{yr}$ MB of the Chhota Shigri Glacier in perspective of glacier mass change in the rest of the western Himalaya.

\section{Site description, data and methodology}

\subsection{Site description}

The Chhota Shigri Glacier $\left(32.2^{\circ} \mathrm{N}, 77.5^{\circ} \mathrm{E}\right)$ is a nonsurging valley-type glacier located in the Chandra-Bhaga River basin of the Lahaul and Spiti Valley, Pir Panjal Range, western Himalaya. Its surface area is $15.7 \mathrm{~km}^{2}$ and it is $9 \mathrm{~km}$ long. It extends from 6263 to $4050 \mathrm{~m}$ a.s.l. This glacier is mainly free of debris, with only $3.4 \%$ of the total glacier area covered with debris of gneiss and granite origin. Below $4300 \mathrm{~m}$ a.s.l., the debris layer is highly heterogeneous, from infra-millimeter silts to big boulders exceeding sometimes several meters. The debris thickness tends to decrease with elevation from the snout at $4050 \mathrm{~m}$ a.s.l. to $4300 \mathrm{~m}$ a.s.l. but is highly variable as a function of the topography and the distance to the glacier margins (Dobhal at al., 1995). A central moraine separates the glacier in two main branches up to $4800 \mathrm{~m}$ a.s.l. The altitude of the equilibrium line for a 
Table 1. Description of glaciers with glaciological MB series in the western Himalaya

\begin{tabular}{|c|c|c|c|c|c|}
\hline $\begin{array}{l}\text { Glacier number and name } \\
\text { (Region/State) }\end{array}$ & Location & $\begin{array}{l}\text { Area } \\
\left(\mathrm{km}^{2}\right)\end{array}$ & MB period & $\begin{array}{l}\text { Mass balance } \\
\left(\mathrm{m} \text { w.e. } \mathrm{yr}^{-1}\right)\end{array}$ & References \\
\hline $\begin{array}{l}\text { 1. Neh Nar } \\
\text { (Jhelum Basin/ } \\
\text { Jammu and Kashmir) }\end{array}$ & $\begin{array}{l}34^{\circ} 16^{\prime} \mathrm{N} \\
75^{\circ} 52^{\prime} \mathrm{E}\end{array}$ & 1.7 & 1975-1984 & -0.53 & Dyurgerov and Meier (2005) \\
\hline $\begin{array}{l}\text { 2. Hamtah* } \\
\text { (Lahaul-Spiti/ } \\
\text { Himachal Pradesh) }\end{array}$ & $\begin{array}{l}32^{\circ} 24^{\prime} \mathrm{N} \\
77^{\circ} 37^{\prime} \mathrm{E}\end{array}$ & 3.2 & $2000-2009$ & -1.46 & GSI (2011) \\
\hline $\begin{array}{l}\text { 3. Chhota Shigri } \\
\text { (Lahaul-Spiti/ } \\
\text { Himachal Pradesh) }\end{array}$ & $\begin{array}{l}32^{\circ} 20^{\prime} \mathrm{N} \\
77^{\circ} 30^{\prime} \mathrm{E}\end{array}$ & 15.7 & $2002-2010$ & -0.67 & $\begin{array}{l}\text { Wagnon et al. (2007) } \\
\text { Azam et al. (2012) }\end{array}$ \\
\hline $\begin{array}{l}\text { 4. Shaune Garang } \\
\text { (Baspa Basin/ } \\
\text { Himachal Pradesh) }\end{array}$ & $\begin{array}{l}31^{\circ} 17^{\prime} \mathrm{N} \\
78^{\circ} 20^{\prime} \mathrm{E}\end{array}$ & 4.9 & $1981-1991$ & -0.42 & GSI (1992) \\
\hline $\begin{array}{l}\text { 5. Gara } \\
\text { (Baspa Basin/ } \\
\text { Himachal Pradesh) }\end{array}$ & $\begin{array}{l}31^{\circ} 28^{\prime} \mathrm{N} \\
78^{\circ} 25^{\prime} \mathrm{E}\end{array}$ & 5.2 & 1974-1983 & -0.32 & Raina et al. (1977); \\
\hline $\begin{array}{l}\text { 6. Naradu } \\
\text { (Baspa basin/ } \\
\text { Himachal Pradesh) }\end{array}$ & $\begin{array}{l}31^{\circ} 20^{\prime} \mathrm{N} \\
78^{\circ} 27^{\prime} \mathrm{E}\end{array}$ & 4.6 & $2000-2003$ & -0.40 & Koul and Ganjoo (2010) \\
\hline $\begin{array}{l}\text { 7. Gor-Garang } \\
\text { (Baspa basin/ } \\
\text { Himachal Pradesh) }\end{array}$ & $\begin{array}{l}31^{\circ} 37^{\prime} \mathrm{N} \\
78^{\circ} 49^{\prime} \mathrm{E}\end{array}$ & 2.0 & 1976-1985 & -0.38 & Dyurgerov and Meier (2005) \\
\hline $\begin{array}{l}\text { 8. Tipra Bank } \\
\text { (Garhwal Himalaya/ } \\
\text { Uttarakhand) }\end{array}$ & $\begin{array}{l}30^{\circ} 44^{\prime} \mathrm{N} \\
79^{\circ} 41^{\prime} \mathrm{E}\end{array}$ & 7.0 & $1981-1988$ & -0.25 & $\begin{array}{l}\text { Dyurgerov and Meier (2005) } \\
\text { Gautam and Mukherjee (1989) }\end{array}$ \\
\hline $\begin{array}{l}\text { 9. Dokriani } \\
\text { (Garhwal Himalaya/ } \\
\text { Uttarakhand) }\end{array}$ & $\begin{array}{l}30^{\circ} 50^{\prime} \mathrm{N} \\
78^{\circ} 50^{\prime} \mathrm{E}\end{array}$ & 7.0 & $\begin{array}{l}1992-1995 \\
\text { and } 1997-2000\end{array}$ & -0.32 & Dobhal et al. (2008) \\
\hline $\begin{array}{l}\text { 10. Dunagiri } \\
\text { (Garhwal Himalaya/ } \\
\text { Uttarakhand) }\end{array}$ & $\begin{array}{l}30^{\circ} 33^{\prime} \mathrm{N} \\
79^{\circ} 54^{\prime} \mathrm{E}\end{array}$ & 2.6 & $1984-1990$ & -1.04 & GSI (1992) \\
\hline $\begin{array}{l}\text { 11. Rulung } \\
\text { (Zanskar Range/ } \\
\text { Jammu and Kashmir) }\end{array}$ & $\begin{array}{l}31^{\circ} 11^{\prime} \mathrm{N} \\
78^{\circ} \mathrm{E}\end{array}$ & 1.1 & 1980-1981 & -0.11 & Srivastava et al. (2001) \\
\hline $\begin{array}{l}\text { 12. Shishram } \\
\text { (Jhelum Basin/ } \\
\text { Jammu and Kashmir) }\end{array}$ & $\begin{array}{l}34^{\circ} 20^{\prime} \mathrm{N} \\
75^{\circ} 43^{\prime} \mathrm{E}\end{array}$ & 9.9 & 1983-1984 & -0.29 & Dyurgerov and Meier (2005) \\
\hline $\begin{array}{l}\text { 13. Kolahoi } \\
\text { (Jhelum Basin/ } \\
\text { Jammu and Kashmir) }\end{array}$ & $\begin{array}{l}34^{\circ} 20^{\prime} \mathrm{N} \\
75^{\circ} 47^{\prime} \mathrm{E}\end{array}$ & 11.9 & $1983-1984$ & -0.27 & Dyurgerov and Meier (2005) \\
\hline
\end{tabular}

zero mass balance is close to $4900 \mathrm{~m}$ a.s.l. (Wagnon et al., 2007). It lies in a region alternatively influenced by the Indian monsoon in summer and the midlatitude westerlies in winter (Bookhagen and Burbank, 2010) with precipitations distributed equally between summer (May-October) and winter
(November-April) months as recorded since 1969 at Bhuntar airport meteorological station (1050 ma.s.1), $31 \mathrm{~km}$ southwest of the Chhota Shigri Glacier. At $5550 \mathrm{~m}$ a.s.1., between 2002 and 2010, annual accumulation varied between 1.0 and $2.2 \mathrm{~m}$ water equivalent (w.e.). 


\subsection{Glaciological mass balance measurements}

The first series of measurements on the Chhota Shigri Glacier started in 1987 (Nijampurkar and Rao, 1992; Dobhal et al., 1995; Kumar, 1999) but the MB measurements were abandoned after 1989. Jawaharlal Nehru University (India) and Institut de Recherche pour le Développement (France) reinitiated the mass-balance observations in 2002. Since that year, annual surface MB measurements have been carried out continuously on the Chhota Shigri Glacier at the end of September or the beginning of October, using the glaciological method (Cuffey and Paterson, 2010). Details about those glaciological MB measurements can be found in Wagnon et al. (2007) and Azam et al. (2012).

\subsection{Geodetic mass balance from field measurements}

Extensive field surveys were carried out on the Chhota Shigri Glacier between 1987 and 1989 in order to perform surface velocity, MB, and gravimetric measurements (Dobhal, 1992; Dobhal et al., 1995; Nijampurkar and Rao, 1992; Kumar, 1999). For this purpose, 48 stakes were set up in the ice in 1987 and 84 in 1988. These stakes, along with 20 gravimetric stations were surveyed in 1988 by topographic measurements using a theodolite and a laser range finder. This resulted in 104 points on the glacier surface, whose position was known in 1988 with a horizontal/vertical accuracy of $0.10 \mathrm{~m}$ (Dobhal, 1992).

In October 2010, 91 of the 104 geodetic points originally measured in 1988 were surveyed again in the field using the carrier-phase global positioning system (GPS) to determine the thickness variations of the glacier over $22 \mathrm{yr}$. The other 13 points were inaccessible due to crevasses. First, the old 1988 (Survey Of India (SOI)) and the new 2010 (UTM-Universal Transverse Mercator) coordinate systems were homogenized thanks to 6 geodetic benchmarks engraved in 1988 in rocks around the glacier. GPS measurements performed on these benchmarks in 2010 allowed us to calculate the local geometric transformation between the SOI and UTM coordinate systems. The residual error was less than $5 \mathrm{~cm}$ in horizontal and vertical components. From this transformation, the coordinates of the 104 points surveyed in 1988 were calculated in the UTM system. Second, we measured the elevations of the glacier surface at these points in order to obtain the thickness changes since 1988 . Finally, these thickness changes are averaged by and applied to every $50 \mathrm{~m}$ altitude range area with data (67\% of the total area), and different thickness variations are tested for the unsurveyed glacier area (see Sect. 3.1 for details). Volume changes are converted into the total cumulative MB over the period 1988-2010, assuming that the mass loss is glacier ice (density $=900 \mathrm{~kg} \mathrm{~m}^{-3}$ ).

\subsection{Geodetic mass balance from spaceborne DEMs}

Regional changes in ice elevation have been measured by differencing two DEMs generated from the 10-20 February 2000 Shuttle Radar Topographic Mission (SRTM; Rabus et al., 2003) and from Satellite Pour l'Observation de la Terre (SPOT 5) optical stereo imagery acquired 20 October 2011 (Korona et al., 2009). The November 2004 SPOT5 DEM from a previous study (Berthier et al., 2007) was also used to revisit previously published MB estimates for this region (Table 2). The glacier outlines were derived from a Landsat ETM+ (Enhanced Thematic Mapper Plus) image acquired 15 October 2000. Clean ice and snow areas are detected automatically by applying a threshold to the normalised difference snow index (TM2 - TM5)/(TM2 + TM5). Debriscovered parts were digitized manually through visual interpretation (Racoviteanu et al., 2009). Our study region includes $2110 \mathrm{~km}^{2}$ of glaciers, $13 \%$ of which is covered with debris.

A complete description of the dataset and the methods we used here to adjust horizontally and vertically the DEMs and account for the C-band (SRTM) penetration into snow and ice can be found in Gardelle et al. (2012a, b). Volume changes are calculated by integrating elevation changes over the whole glaciarized area or over individual glaciers, and a density of $900 \mathrm{~kg} \mathrm{~m}^{-3}$ is used for the volume-to-mass conversion. A seasonality correction, to cover 12 complete 12 month periods from October 1999 to October 2011, must be applied between mid-October 1999 and mid-February 2000, a 4-month period when glaciers are accumulating mass. Given the lack of measurement of winter MB in the Lahaul and Spiti region our correction is based on a global mean winter MB of ca. $1 \mathrm{~m}$ w.e. assuming a 7-month duration of the accumulation season (typically from 15 September to 15 April of the following year). Thus, we applied a correction of $0.15 \mathrm{~m}$ w.e. per winter month (Ohmura, 2011) and assigned a high uncertainty $(100 \%)$ to this correction.

\section{Results}

\subsection{Changes in Chhota Shigri Glacier thickness and cumulative MB over the period 1988-2010}

The thickness variations derived from the changes in elevation measured at each of the 91 points are plotted in Figs. 2 and 3. Except for the glacier tongue, we observe an overall uniform decrease in thickness changes with increasing altitude, with thinning ranging from $\sim-8 \mathrm{~m}$ at $4500 \mathrm{~m}$ a.s.l. to $-5 \mathrm{~m}$ at $5100 \mathrm{~m}$ a.s.l. (Figs. 2 and 3). Below $4500 \mathrm{~m}$ a.s.l., the thickness change differs from this trend. This could be due to the presence of debris cover, which affects the sensitivity of ice ablation to solar radiation (e.g. Brock et al., 2000). Given that the debris cover comes from sporadic rock falls or landslides and moves following the ice flow, the influence 
Table 2. Characteristics of the remotely-sensed DEMs used in this study.

\begin{tabular}{llllll}
\hline Sensor & Date & Coverage & Posting & Method & Reference \\
\hline SRTM & $\sim$ 10-20 Feb. 2000 & quasi global $(56 \mathrm{~S}$ to $60 \mathrm{~N})$ & $90 \mathrm{~m}$ & SAR interferometry & Rabus et al., 2003 \\
SPOT5-HRG & 12-13 Nov. 2004 & $868 \mathrm{~km}^{2}$ of glaciers & $90 \mathrm{~m}$ & Across-track stereo-imagery & Berthier et al., 2007 \\
SPOT5-HRS & 20 Oct. 2011 & $2110 \mathrm{~km}^{2}$ of glaciers & $40 \mathrm{~m}$ & Along-track stereo-imagery & Korona et al., 2009 \\
\hline
\end{tabular}

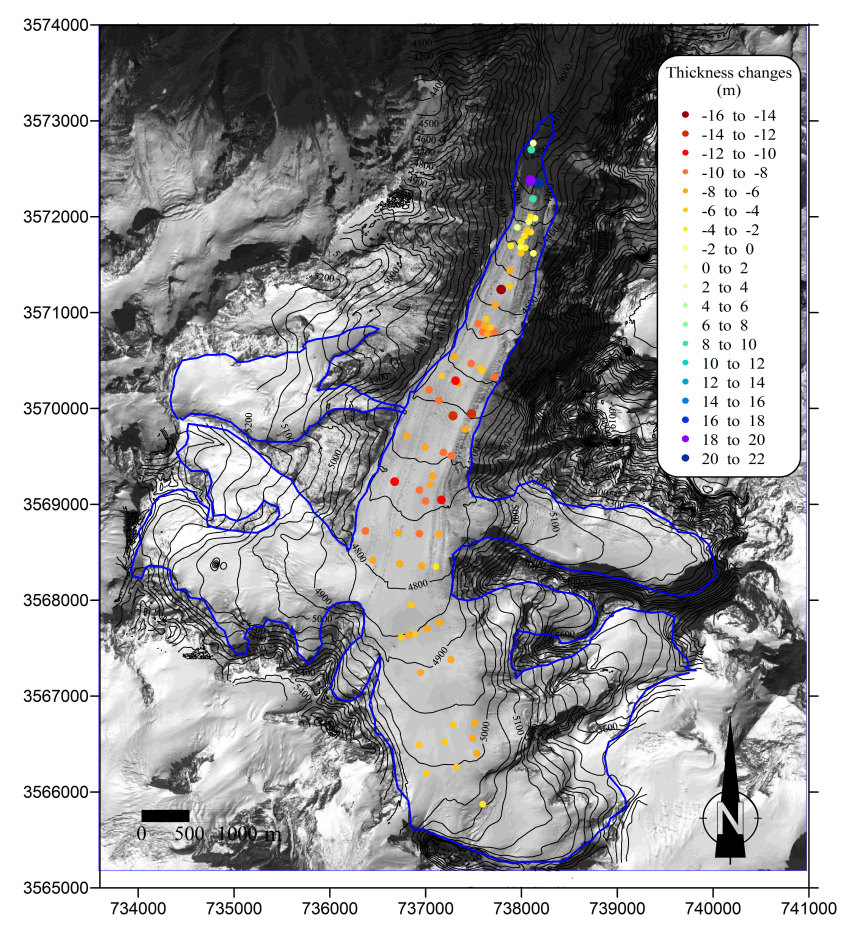

Fig. 2. Thickness changes of the Chhota Shigri Glacier measured between 1988 and 2010, using geodetic measurements (coloured dots). The map coordinates are in the UTM43 (north) WGS84 (World Geodetic System) reference system.

on thickness changes varies a lot with space, as observed on other alpine glaciers (e.g. Berthier and Vincent, 2012). Between 4300 and $4500 \mathrm{~m}$ a.s.l., the debris cover is nonuniform and the thinning does not exceed $-4 \mathrm{~m}$ (Fig. 2). The snout region between 4050 and $4300 \mathrm{~m}$ a.s.l. (1\% only of the total glacier area), surrounded by very steep slopes and consequently heavily covered by debris, shows thickening that may be due to locally important snow avalanche or landslides (part of this snout region is an avalanche deposition area). Although the thickness changes are very heterogeneous below $4500 \mathrm{~m}$ a.s.l., it hardly affects the glacier-wide MB given that the surface area covered by debris is only $3.4 \%$ of the total glacier area. Above $5100 \mathrm{~m}$ a.s.1. (33\% of the glacier area), no measurement of elevation change is available.

Our 1988-2010 geodetic field measurements are restricted to the main trunk of the Chhota Shigri (CS) Glacier and did not sample the tributaries. To verify that no bias was induced

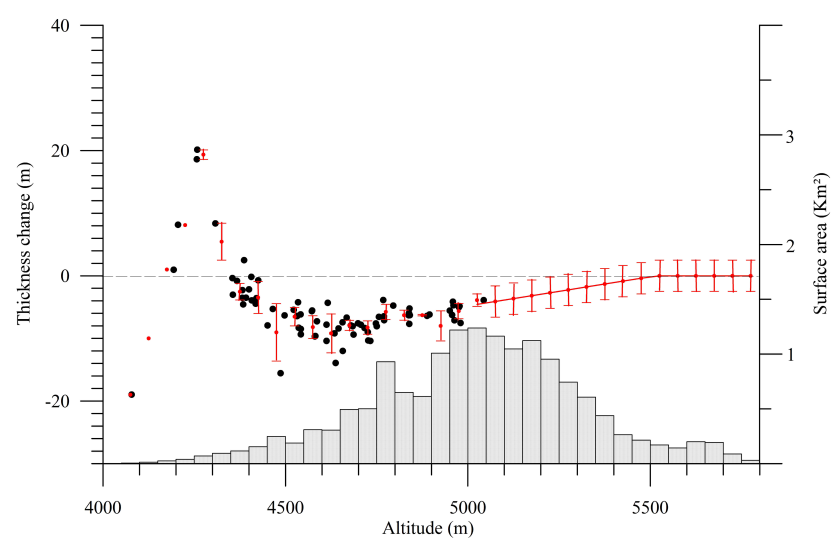

Fig. 3. Thickness changes as a function of altitude (measurements (black dots)). Below $5100 \mathrm{~m}$ a.s.1., mean thickness changes have been calculated within each altitude range from measurements (red dots). Above $5100 \mathrm{~m}$, the thinning trend observed between 4700 and $5100 \mathrm{~m}$ has been extrapolated using a linear regression with altitude to zero mass balance (red dots).

by this incomplete sampling, we averaged the 1999-2011 remotely-sensed elevation changes of the tributaries and the main trunk between $4700 \mathrm{~m}$ a.s.l., the lower limit of the tributaries, and $5100 \mathrm{~m}$ a.s.1, the uppermost altitude of the 19882010 geodetic field measurements. At $-9.2 \mathrm{pm} 1.5 \mathrm{~m}$ for the tributaries (area with valid measurements: $2.0 \mathrm{~km}^{2}$ ) and $8.9 \pm 1.3 \mathrm{~m}$ for the main trunk (area with valid measurements: $2.8 \mathrm{~km}^{2}$ ), the mean elevation changes are very similar and not statistically different at the 1-sigma level. This observation justifies our assumption that field geodetic measurements on the main trunk are representative of the rest of the CS Glacier below $5100 \mathrm{~m}$ a.s.l.

On average, below $5100 \mathrm{~m}$ a.s.1., the 22-yr thinning is $5.6 \mathrm{~m}$ of ice, i.e. $-5.0 \mathrm{~m}$ w.e. The total volume change of the glacier was calculated using three different assumptions to capture the entire range of changes that could reasonably be expected for the unsurveyed area. First, thinning above $5100 \mathrm{~m}$ a.s.l. was assumed to be equal to that measured in the lower part, resulting in a cumulative $\mathrm{MB}$ of the glacier of $-5.0 \mathrm{~m}$ w.e. between 1988 and 2010. Second, the upper part of the glacier was assumed to have experienced no elevation change since 1988, giving a cumulative MB of $3.3 \mathrm{~m}$ w.e. over the $22 \mathrm{yr}$. Third, the decreasing thinning trend observed between 4700 and $5100 \mathrm{~m}$ a.s.1. was extrapolated 
from the lower to the upper part, using a linear regression with altitude. This results in a cumulative $\mathrm{MB}$ of $-3.8 \mathrm{~m}$ w.e. This third assumption seems to be the most reasonable given that, over a period of several decades, the elevation changes of nonsurging glaciers generally approach zero toward the head of the glacier (Schwitter and Raymond, 1993).

A first source of error comes from the uncertainty associated with elevation changes in each altitude range. In the lower part of the glacier, below $4300 \mathrm{~m}$ a.s.l., for which the debris layer is highly heterogeneous, the uncertainty is assumed to be $\pm 5 \mathrm{~m}$ w.e. Between 4300 and $5100 \mathrm{~m}$ a.s.l., where many measurements are available, the standard deviation of measured elevation changes within each altitude range is $1.2 \mathrm{~m}$ w.e. on average. In the unsurveyed upper part, where the thinning is assumed to be between 0 and $-5 \mathrm{~m}$ w.e., this uncertainty is higher and assumed to be $\pm 2.5 \mathrm{~m}$ w.e. Weighting these uncertainties with the areas, the total uncertainty of the mean elevation change of the glacier is $1.8 \mathrm{~m}$ w.e. The area change between 1988 and 2010, which affects the calculation of the volume change can be neglected because the snout retreated by only $155 \mathrm{~m}$ (Azam et al., 2012) in $22 \mathrm{yr}$, corresponding to an insignificant surface area loss $(<0.1 \%$ of the total surface area).

Another source of error comes from the choice of ice density to convert the volume change into MB. This is straightforward in the ablation zone where only ice is lost, but not so easy to estimate in the accumulation area where either firn or ice can be lost. As a sensitivity test, we also considered a density of $600 \mathrm{~kg} \mathrm{~m}^{-3}$ instead of $900 \mathrm{~kg} \mathrm{~m}^{-3}$ for the material lost above $4900 \mathrm{~m}$ a.s.l. (Kääb et al., 2012). The cumulative MB between 1988 and 2010 becomes -4.1, 3.0 and $-3.3 \mathrm{~m}$ w.e. for assumptions 1 (same thinning above $5100 \mathrm{~m}$ a.s.l. as below), 2 (no thinning above $5100 \mathrm{~m}$ a.s.l.) and 3 (linear thinning) respectively. Consequently, the calculations with these two extreme-density scenarios show that the maximum error due to unknown density is $0.9 \mathrm{~m}$ w.e. This error is summed quadratically with the error on elevation changes $(1.8 \mathrm{~m}$ w.e.) to obtain a total error of $2.0 \mathrm{~m}$ w.e. or $0.09 \mathrm{~m}$ w.e. $\mathrm{yr}^{-1}$.

\subsection{Geodetic mass balance of the Chhota Shigri and surrounding glaciers during 1999-2004, 2004-2011 and 1999-2011}

To deduce the MB of the Chhota Shigri Glacier during 19881999 from the 1988-2010 geodetic MB, two options were available to us: (i) sum the 1999-2004 geodetic MB (Berthier et al., 2007) and the 2004-2010 glaciological MB (Azam et al., 2012); or (ii) estimate the 1999-2011 geodetic MB and subtract one year (2010-2011) of glaciological MB. The two first subsections below aim at selecting the better of these two strategies. To do so, we had first to revisit the 19992004 geodetic MB using up-to-date DEM adjustment methods. The third subsection deals with the regional representativeness of the Chhota Shigri Glacier.
Table 3. Comparison of the 1999-2004 geodetic MB published previously (Berthier et al., 2007) and the revised values using up-todate corrections and error analysis (Gardelle et al., 2012a, b). In the 2007 publication, no error analysis was performed but two values were provided corresponding to two density scenarios for the volume-to-mass conversion in the accumulation area.

\begin{tabular}{lcc}
\hline & Chhota Shigri $^{\mathrm{a}}$ & Whole region $^{\mathrm{b}}$ \\
\hline Area $\left(\mathrm{km}^{2}\right)$ & 15.7 & 867.9 \\
MB RSE-2007 (m w.e. $\left.\mathrm{yr}^{-1}\right)$ & $-1.12 /-1.02$ & $-0.85 /-0.69$ \\
MB This study (m w.e. $\left.\mathrm{yr}^{-1}\right)$ & $-1.03 \mathrm{pm} 0.44$ & $-0.65 \mathrm{pm} 0.17$ \\
\hline
\end{tabular}

${ }^{a}$ the Chhota Shigri Glacier area was $16.5 \mathrm{~km}^{2}$ in Berthier et al. (2007) but revised to $15.7 \mathrm{~km}^{2}$ in Wagnon et al. (2007), based on new glacier outlines drawn on high resolution imagery and verified using field observations. It illustrates the difficulty of delimitating debris-covered glacier fronts from satellite imagery solely.

$\mathrm{b}$ the total ice-covered inventory was $915.5 \mathrm{~km}^{2}$ in Berthier et al. (2007) but only $867.8 \mathrm{~km}^{2}$ were actually covered with the 2004 Spot5-HRG DEM.

\subsubsection{Published and revised 1999-2004 MB}

In a previous publication (Berthier et al., 2007), we have compared the SRTM DEM (February 2000) and a November 2004 SPOT5 DEM (Table 2) to measure the region-wide MB of ca. $900 \mathrm{~km}^{2}$ of glaciers (including the Chhota Shigri Glacier). Due to penetration into snow/firn of the radar signal, the SRTM DEM was assumed to represent the altitude of the glacier surface at the end of the 1999 melt season and thus the time stamp for the MB was 1999-2004. Further Cband penetration into ice was neglected. Various corrections were applied to the differential DEM, in particular a correction for an elevation-dependent bias estimated on the stable terrain and applied directly to the glacier areas.

Since 2007, advances have been made to understand what was initially referred as an "elevation bias" in the SRTM DEM (Berthier et al., 2006). Paul (2008) attributed this bias to the difference in resolution of the DEMs and suggested that no correction was needed. Building upon those findings, Gardelle et al. (2012a) recommended a correction of this "resolution bias" using a relationship between elevation difference and maximum curvature. The latter authors also proposed a first-order estimate of the radar penetration into snow/firn/ice by comparing two DEMs acquired simultaneously during the SRTM mission in X and $\mathrm{C}$ bands. Using these improved corrections, we present here revised values for the 1999-2004 geodetic MB together with their uncertainties, calculated following Gardelle et al. (2012b).

The published and revised 1999-2004 MB for the Chhota Shigri Glacier (Table 3) differ only slightly, by less than $0.1 \mathrm{~m}$ w.e. $\mathrm{yr}^{-1}$. However, due to the relatively small size of the glacier $\left(15.7 \mathrm{~km}^{2}\right)$ and the short time separation $(5 \mathrm{yr})$, the uncertainty for the revised $\mathrm{MB}$ is as large as $\pm 0.44 \mathrm{~m}$ w.e. $\mathrm{yr}^{-1}$. Thus, we cannot rule out that this agreement between the published and revised MB is coincidental. At $-0.65 \mathrm{pm} 0.17 \mathrm{~m}$ w.e. $\mathrm{yr}^{-1}$, the regional $\left(868 \mathrm{~km}^{2}\right.$ 


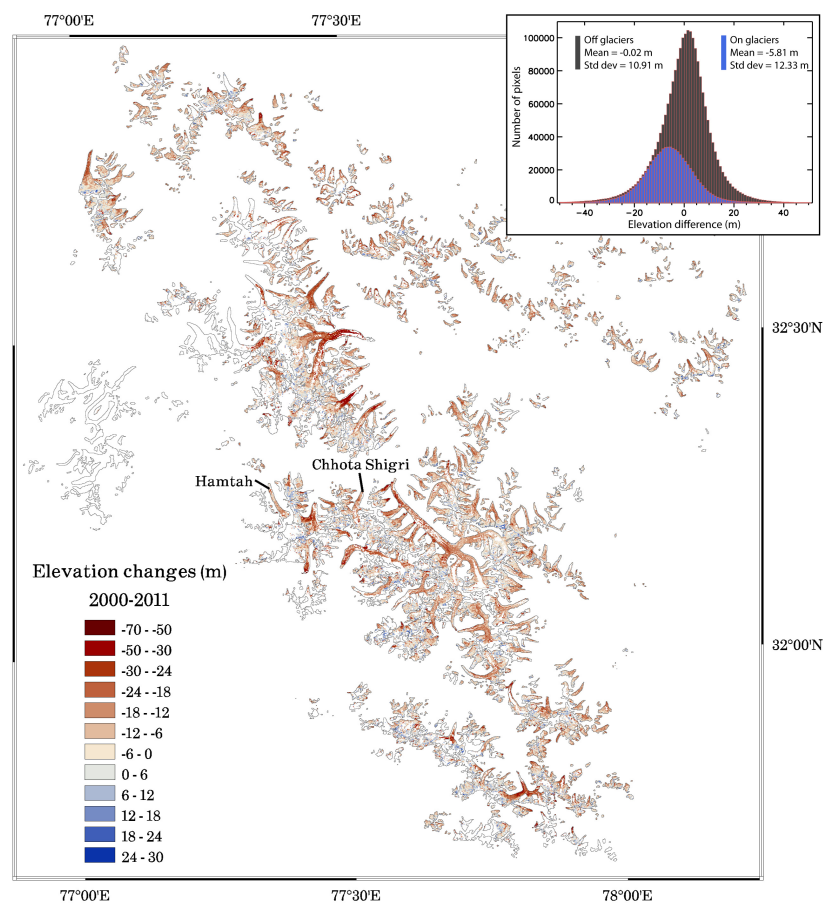

Fig. 4. Map of elevation changes between February 2000 and October 2011 for $2110 \mathrm{~km}^{2}$ of glaciers in the Lahaul and Spiti region. The inset shows the distribution, mean and standard deviation of the elevation changes on/off glaciers. The map of elevation changes off glaciers is shown as Appendix (Fig. A1).

of glaciers) MB is now slightly less negative than published in the 2007 paper. Nevertheless, the statement that glaciers in the Lahaul/Spiti lost mass rapidly between 1999 and 2004 remains unchallenged.

\subsubsection{Geodetic MB for 1999-2004, 2004-2011 and 1999-2011}

Given the availability of the 3 DEMs (Table 2), MB can be calculated for three different time periods and their internal consistency can be checked using triangulation (e.g. Nuth and Kääb, 2011). No correction of the penetration into snow/firn/ice is needed when the SPOT5-HRG 2004 and SPOT5-HRS 2011 DEMs are compared because both those DEMs are derived from optical imagery. Figure 4 shows the regional pattern of elevation changes between 1999 and 2011 for a glaciarized area covering in total $2110 \mathrm{~km}^{2}$. Figure 5 shows the distribution of elevation changes for the Chhota Shigri and Hamtah glaciers for the same period.

In Table 4, we compare the geodetic MB for 1999-2004 $\left(\right.$ period I, MB $\left.{ }^{\mathrm{I}}\right), 2004-2011$ (period II, MB $\left.{ }^{\mathrm{II}}\right)$, and 19992011 (period III, MB ${ }^{\text {III }}$ ). Ideally, the time-weighted sum of $\mathrm{MB}^{\mathrm{I}}$ and $\mathrm{MB}^{\mathrm{II}}$ (noted $\mathrm{MB}^{\mathrm{I}+\mathrm{II}}$ ) should equal $\mathrm{MB}^{\mathrm{III}}$. The difference between $\mathrm{MB}^{\mathrm{I}+\mathrm{II}}$ and $\mathrm{MB}^{\mathrm{III}}$ reaches $0.36 \mathrm{~m}$ w.e. $\mathrm{yr}^{-1}$ for the Chhota Shigri Glacier, which highlights the challenge of computing the MB of small to medium size indi-
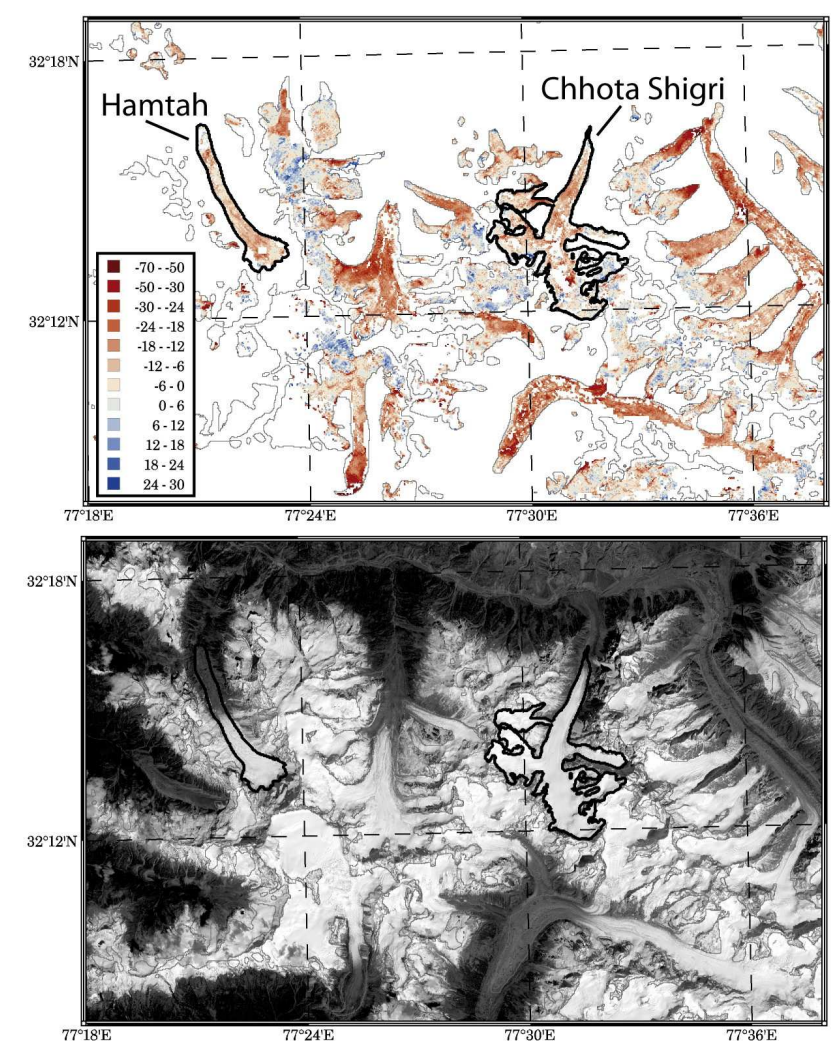

Fig. 5. Upper panel. Detail view of the elevation changes (m) on Chhota Shigri, Hamtah and their neighbouring glaciers between February 2000 and October 2011. Lower panel: SPOT5 HRG image of the corresponding area acquired in October 2005.

vidual glaciers from coarse DEMs acquired only a few years apart, and the importance of averaging over large regions. Indeed, the difference between $\mathrm{MB}^{\mathrm{I}+\mathrm{II}}$ and $\mathrm{MB}^{\mathrm{III}}$ is only $0.08 \mathrm{~m}$ w.e. $\mathrm{yr}^{-1}$ for $868 \mathrm{~km}^{2}$ of glaciers in the Lahaul and Spiti region.

Part of the differences between $\mathrm{MB}^{\mathrm{I}+\mathrm{II}}$ and $\mathrm{MB}^{\mathrm{III}}$ in Table 4 may be due to a varying sampling of the glaciers during the different time intervals due to clouds, shadows or lack of image texture in the accumulation areas. For example, the lower reaches of the Chhota Shigri Glacier were poorly mapped by the November 2004 SPOT5 DEM due to considerable shadows from the surrounding steep slopes at this time of year. This affects $\mathrm{MB}^{\mathrm{I}}$ and $\mathrm{MB}^{\mathrm{II}}$ but not MB ${ }^{\mathrm{III}}$. Similarly, there are clouds in part of the 2011 DEM, which affect the "whole region" estimates $\mathrm{MB}^{\mathrm{II}}$ and $\mathrm{MB}^{\mathrm{III}}$ but not $\mathrm{MB}^{\mathrm{I}}$. For this reason, we also provided in Table 5 the MB for each period when exactly the same spatial sampling is applied to all glaciers, i.e. always neglecting pixels that are unreliable in at least one of the DEMs. For the Chhota Shigri Glacier, in this case, valid pixels cover only one third of the glacier area and are not representative of the glacier hypsometry (Fig. 6). After this homogenization, the difference between $\mathrm{MB}^{\mathrm{I}+\mathrm{II}}$ and $\mathrm{MB}^{\mathrm{III}}$ for the Chhota Shigri Glacier is reduced from $0.36 \mathrm{~m}$ w.e. $\mathrm{yr}^{-1}$ 

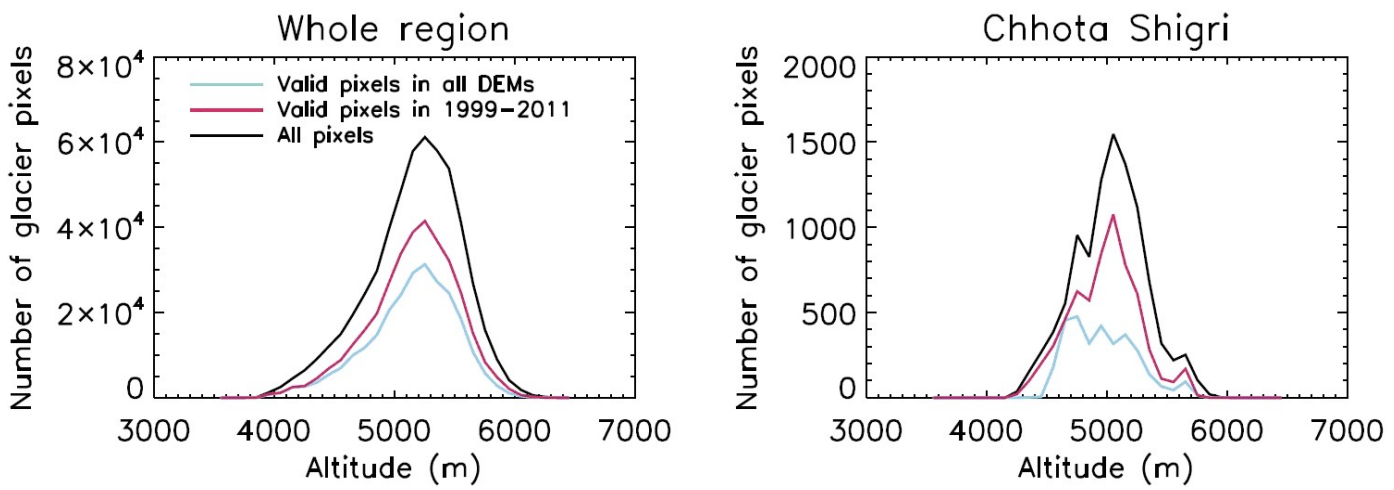

Fig. 6. Hypsometry of the ice-covered area of the whole region studied by Berthier et al. (2007), (left, $868 \mathrm{~km}^{2}$ in total) and the Chhota Shigri Glacier (right, $15.7 \mathrm{~km}^{2}$ ) and its sampling by the differential DEMs. The black curve corresponds to all pixels, the grey curve to DEM pixels that are valid in the 1999-2011 differential DEM, and the blue curve to the pixels that are valid in all DEMs (1999, 2004 and 2011). Those distributions show that the whole region is well-sampled in all cases, whereas for the Chhota Shigri Glacier, the 1999-2011 sampling is adequate but not the sampling by valid pixels in all three DEMs.

Table 4. Geodetic MB during 1999-2004, 2004-2011 and 1999-2011. All values in this table are calculated using the correction and error analysis proposed by Gardelle et al. (2012a, b). For each time interval, all valid DEM pixels are used contrary to Table 5 below, in which only pixels which are valid simultaneously in all three DEMs are used.

\begin{tabular}{lll}
\hline & Chhota Shigri & Whole region \\
\hline Ice-covered area $\left(\mathrm{km}^{2}\right)$ & 15.7 & 867.9 \\
$\mathrm{MB}^{\mathrm{I}}\left(\mathrm{m}\right.$ w.e. $\left.\mathrm{yr}^{-1}\right): 1999-2004$ & $-1.03 \pm 0.44$ & $-0.65 \pm 0.17$ \\
$\mathrm{MB}^{\mathrm{II}}\left(\mathrm{m}\right.$ w.e. $\left.\mathrm{yr}^{-1}\right): 2004-2011$ & $-0.55 \pm 0.42$ & $-0.42 \pm 0.05$ \\
$\mathrm{MB}^{\mathrm{I}+\mathrm{II}}\left(\mathrm{m}\right.$ w.e. $\left.\mathrm{yr}^{-1}\right):\left(5 \times \mathrm{MB}^{\mathrm{I}}+7 \times \mathrm{MB}^{\mathrm{II}}\right) / 12$ & $-0.75 \pm 0.31$ & $-0.52 \pm 0.08$ \\
$\mathrm{MB}^{\mathrm{III}}\left(\mathrm{m}\right.$ w.e. $\left.\mathrm{yr}^{-1}\right): 1999-2011$ & $-0.39 \pm 0.15$ & $-0.44 \pm 0.09$ \\
\hline
\end{tabular}

to $0.16 \mathrm{~m}$ w.e. $\mathrm{yr}^{-1}$ (Table 4 and 5). When the whole region is considered $\left(868 \mathrm{~km}^{2}\right.$ of glaciers of which $409 \mathrm{~km}^{2}$ are covered by valid pixels in all three DEMs), this difference, initially at $0.08 \mathrm{~m}$ w.e. $\mathrm{yr}^{-1}$, is reduced to only $0.01 \mathrm{~m}$ w.e. $\mathrm{yr}^{-1}$.

These observations confirm the excellent relative adjustment of the DEMs when their full extent is considered but also that local elevation biases remain, leading to error on MB for individual glaciers (here the Chhota Shigri Glacier). This is not surprising given that our method of DEM adjustment aims at minimizing the elevation differences for the whole ice-free terrain present in the DEMs. Locally, some elevation differences may persist due to incorrectly modelled short wavelength (typically $\mathrm{km}$-scale) errors in the DEMs (Nuth and Kääb, 2011; Berthier et al., 2012). These local elevation biases lead to errors in the MB for individual glaciers and, thus, care must be taken before computing the geodetic $\mathrm{MB}$ for a single glacier covering a few $\mathrm{km}^{2}$ or tenths of $\mathrm{km}^{2}$, especially when the DEMs have a short time separation. Fortunately, those errors average out when the whole glaciarized area, spread in the complete DEM extent, is considered.

The 1999-2011 assessment (MB ${ }^{\text {III }}$ ) provides the best sampling of the Chhota Shigri Glacier (Figs. 5 and 6) and the smallest error bars due to the longest time separation. To re- construct the MB of the Chhota Shigri Glacier between 1988 and 1999 , it is, thus, preferable to use this $12 \mathrm{yr}$ estimate (1999-2011) and one year of field MB (2010-2011) instead of using the 1999-2004 geodetic estimates combined with the cumulative field MB between 2004 and 2011.

\subsubsection{Regional representativeness of Chhota Shigri Glacier}

We used the 1999-2011 geodetic MB to assess the representativeness of the Chhota Shigri Glacier. With $-0.39 \pm 0.15 \mathrm{~m}$ w.e. $\mathrm{yr}^{-1}$ (a cumulative $12 \mathrm{yr} \mathrm{MB}$ of $-4.7 \pm 1.8 \mathrm{~m}$ w.e.), the average glacier-wide $\mathrm{MB}$ for the Chhota Shigri Glacier is not statistically different from the region-wide $\left(2110 \mathrm{~km}^{2}\right.$ of glaciers $) \mathrm{MB}$ of $0.44 \pm 0.09 \mathrm{mw}$.e. $\mathrm{yr}^{-1}$. Also in favour of the regional representativeness of the Chhota Shigri Glacier, a good agreement was found between the glaciological and the regional (a $2^{\circ}$ latitude $\times 2^{\circ}$ longitude cell centered around the Chhota Shigri Glacier) ICESat-derived (Ice, Cloud,and land Elevation Satellite) cumulative MB between fall 2003 and fall 2008 (Kääb et al., 2012, their Supplementary Fig. S6). Those data indicate that the Chhota Shigri Glacier 
Table 5. Geodetic MB during 1999-2004, 2004-2011 and 1999-2011. All values in this table are calculated using the correction and error analysis proposed by Gardelle et al. (2012a, b). For each time interval, all valid DEM pixels are used contrary to Table 5 below, in which only pixels that are valid simultaneously in all three DEMs are used.

\begin{tabular}{lll}
\hline & Chhota Shigri & Whole region \\
\hline Ice-covered area $\left(\mathrm{km}^{2}\right)$ & 15.7 & 867.9 \\
$\mathrm{MB}^{\mathrm{I}}\left(\mathrm{m}\right.$ w.e. $\left.\mathrm{yr}^{-1}\right): 1999-2004$ & $-1.03 \pm 0.44$ & $-0.65 \pm 0.17$ \\
$\mathrm{MB}^{\mathrm{II}}\left(\mathrm{m}\right.$ w.e. $\left.\mathrm{yr}^{-1}\right): 2004-2011$ & $-0.55 \pm 0.42$ & $-0.42 \pm 0.05$ \\
$\mathrm{MB}^{\mathrm{I}+\mathrm{II}}\left(\mathrm{m} \mathrm{w} \cdot \mathrm{e} \cdot \mathrm{yr}^{-1}\right):\left(5 \times \mathrm{MB}^{\mathrm{I}}+7 \times \mathrm{MB}^{\mathrm{II}}\right) / 12$ & $-0.75 \pm 0.31$ & $-0.52 \pm 0.08$ \\
$\mathrm{MB}^{\mathrm{III}}\left(\mathrm{m}\right.$ w.e. $\left.\mathrm{yr}^{-1}\right): 1999-2011$ & $-0.39 \pm 0.15$ & $-0.44 \pm 0.09$ \\
\hline
\end{tabular}

Table 6. Same as Table 4 but using only pixels that are valid in all three DEMs to avoid the sampling issues described in Sect. 3.2.2. This table is only provided to show how a different sampling can explain the differences between $\mathrm{MB}^{\mathrm{I}+\mathrm{II}}$ and $\mathrm{MB}^{\mathrm{III}}$. However, MB values in Table 4 should be preferred because they are based on the best coverage of glaciers.

\begin{tabular}{lll}
\hline & Chhota Shigri & Whole region \\
\hline Ice-covered area $\left(\mathrm{km}^{2}\right)$ & 15.7 & 867.9 \\
Ice-covered area, valid pixels only $\left(\mathrm{km}^{2}\right)$ & 5.1 & 408.7 \\
$\mathrm{MB}^{\mathrm{I}}\left(\mathrm{m}\right.$ w.e. $\left.\mathrm{yr}^{-1}\right): 1999-2004$ & $-1.09 \pm 0.53$ & $-0.71 \pm 0.18$ \\
$\mathrm{MB}^{\mathrm{II}}\left(\mathrm{m}\right.$ w.e. $\left.\mathrm{yr}^{-1}\right): 2004-2011$ & $-0.28 \pm 0.47$ & $-0.34 \pm 0.05$ \\
$\mathrm{MB}^{\mathrm{I}+\mathrm{II}}\left(\mathrm{m}\right.$ w.e. $\left.\mathrm{yr}^{-1}\right):\left(5 \times \mathrm{MB}^{\mathrm{I}}+7 \times \mathrm{MB}^{\mathrm{II}}\right) / 12$ & $-0.62 \pm 0.35$ & $-0.49 \pm 0.08$ \\
$\mathrm{MB}^{\mathrm{III}}\left(\mathrm{m}\right.$ w.e. $\left.\mathrm{yr}^{-1}\right): 1999-2011$ & $-0.46 \pm 0.19$ & $-0.48 \pm 0.08$ \\
\hline
\end{tabular}

is regionally representative for the first decade of the 21 st century. In the discussion, we discuss whether this statement holds for previous decades.

\subsubsection{Balanced or slightly positive mass budget of Chhota Shigri Glacier between 1988 and 1999}

We combined the direct glaciological measurements (20102011) with the geodetic data using ground (1988-2010) and spaceborne data (1999-2011) to infer the 1988-1999 MB (Table 6). The MB of the Chhota Shigri Glacier measured in the field for the year 2010-2011 using the glaciological method was $+0.1 \pm 0.4 \mathrm{~m}$ w.e. $\mathrm{yr}^{-1}$, which, combined with the cumulative MB of $-4.7 \pm 1.8$ m w.e. between 1999 and 2011 , leads to a cumulative MB of $-4.8 \pm 1.8 \mathrm{~m}$ w.e. between 1999 and 2010. Given that the cumulative MB obtained from geodetic ground data was $-3.8 \pm 2.0 \mathrm{~m}$ w.e. (Sect. 3.1) between 1988 and 2010, the Chhota Shigri Glacier slightly gained mass or experienced balanced conditions between 1988 and 1999 (cumulative MB of $+1.0 \pm 2.7 \mathrm{~m}$ w.e. or $+0.09 \pm 0.24 \mathrm{~m}$ w.e. $\left.\mathrm{yr}^{-1}\right)$ and lost mass over the period 1999-2011 (cumulative MB of $-4.7 \pm 1.8 \mathrm{~m}$ w.e. corresponding to $-0.39 \pm 0.15 \mathrm{~m}$ w.e. $\mathrm{yr}^{-1}$ ). Those MB are decadal averages, a limitation inherent to the geodetic method. Thus, we cannot better constrain when the transition from balanced (or slightly positive) to negative mass budget occurred. Although our results indicate a slightly positive or near-zero MB in the
Table 7. Combination of geodetic and glaciological mass balance (m w.e.).

\begin{tabular}{|c|c|c|}
\hline & 1988 & 2010 \\
\hline $\begin{array}{l}\text { Geodetic mass balance } \\
\text { from field measurements }\end{array}$ & $-3.8(2.0)$ & \\
\hline Glaciological mass balance & & $+0.1(0.4)$ \\
\hline $\begin{array}{l}\text { Geodetic mass balance } \\
\text { from remote sensing }\end{array}$ & $-4.7(1.8)$ & \\
\hline $\begin{array}{l}\text { Mass balance infered from } \\
\text { previous geodetic and } \\
\text { glaciological mass balance }\end{array}$ & $+1.0(2.7)$ & \\
\hline
\end{tabular}

1990s, no evidence of glacier advance could be observed in the field, or on satellite images.

\section{Discussion}

The MB series of the Chhota Shigri Glacier measured since 2002 using the glaciological method has been extended back to 1988 using geodetic measurements. Over the whole period 1988-2010, the cumulative MB of the Chhota Shigri Glacier was $-3.8 \pm 1.8 \mathrm{~m}$ w.e., corresponding to a moderate mass loss rate of $-0.17 \pm 0.08 \mathrm{~m}$ w.e. $\mathrm{yr}^{-1}$. In fact, this 


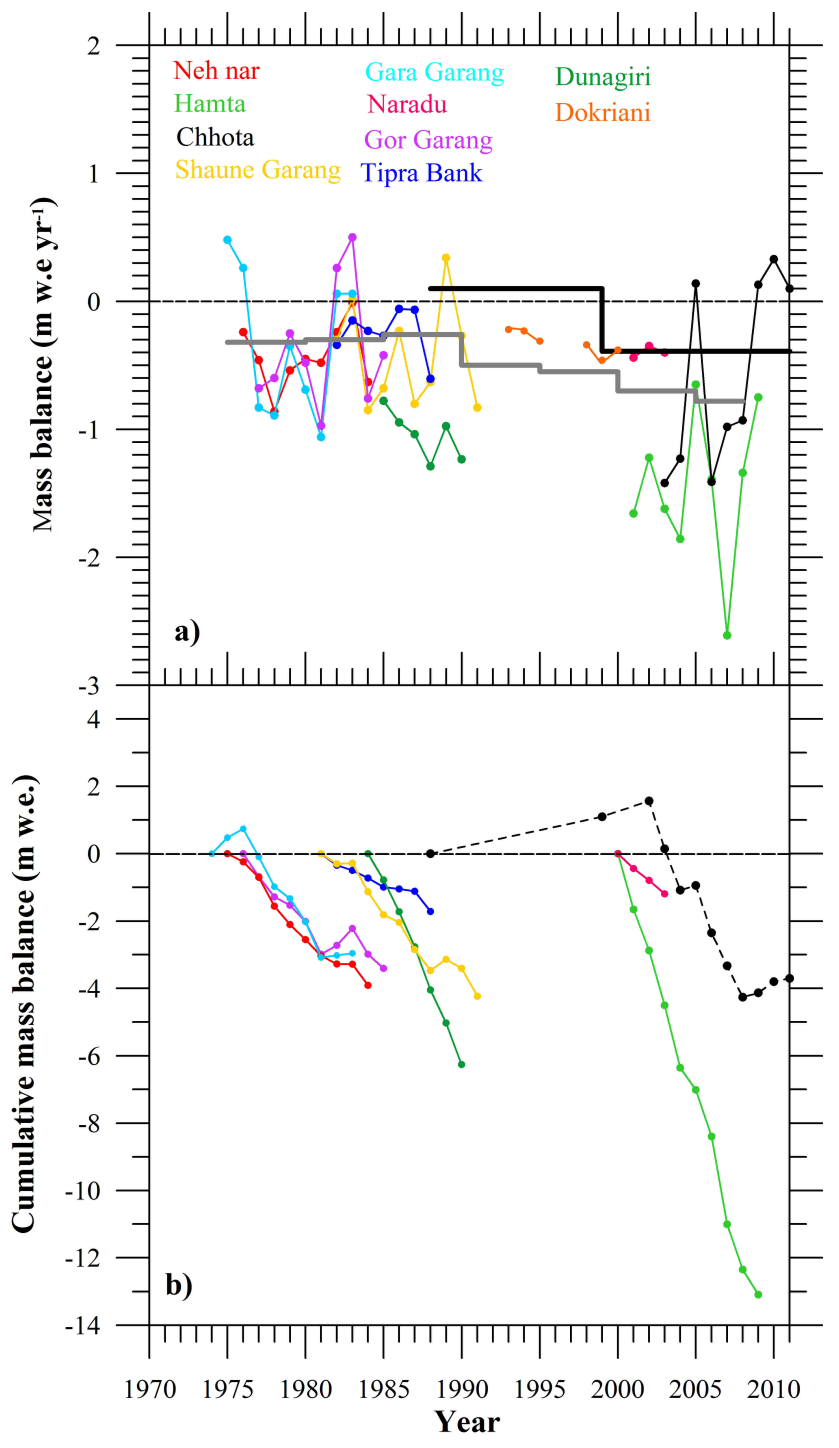

Fig. 7. MB of western Himalayan glaciers. (a) Annual glacier-wide MB of glaciers with more than one year of observations. The grey thick line corresponds to the pentadal Himalaya-Karakoram averages from Cogley (2011). The black thick line comes from geodetic measurements of the Chhota Shigri Glacier, (b) cumulative MB.

glacier experienced first a slightly positive or near-zero cumulative MB between 1988 and 1999 followed by a period of ice wastage, confirming the presumption of Azam et al. (2012). Azam et al. (2012) could only infer indirectly and qualitatively a steady state of the glacier before 2002, based on a dynamical approach. Here, we are able to quantify this near-zero or slightly positive MB based on space-borne and field data of elevation differences available since 1988. Nevertheless, our dataset with a decadal time resolution (controlled by the availability of topographic data) does not allow us to resolve when the glacier shifted from near equilibrium to imbalance, but at the latest, this shift occurred in 1999.

\subsection{Comparison to other MB measurements}

Available MB field data from other glaciers (some of them being partially debris-covered) in the western Himalaya have been compiled to obtain an up-to-date overview of their mass change over recent decades (Table 1; Fig. 7). Several MB series in India started during the seventies but stopped during the eighties. The longest series reported over this period are those of the Gara (9 yr; 1974-1983), Gor Garang (9 yr; 19761985), and Shaune Garang (10 yr; 1981-1991) glaciers, all located in the Baspa Basin, Himachal Pradesh. Recent series longer than $5 \mathrm{yr}$ are those of the Hamtah, Dokriani, and Chhota Shigri glaciers. The Hamtah Glacier MB series started in 2000 but annual data after 2009 are not available. The Dokriani measurements started in 1991 and stopped in 2000, with a gap in 1995 and 1996, before starting again in 2007. Figure 7 also includes the pentadal average MB of the Himalaya-Karakoram (HK) region (Cogley, 2011; Bolch et al., 2012). Figure 7, shows that the observations available on other glaciers of western Himalaya are mostly limited to the period 1975-1990, when glaciers experienced mostly negative MB, except for some years. During the nineties, MBs are available only for the Dokriani Glacier but, unfortunately, these measurements are intermittent between 1991 and 2010 and do not allow us to obtain MB changes over the last two decades. Thus, this present study is filling a gap in the knowledge of western Himalaya glacier MB in the 1990s.

A positive or near-zero MB for the Chhota Shigri Glacier in the 1990s departs from the most recent compilation for the entire HK (Bolch et al., 2012). This compilation indicates ice wastage over the past five decades with an increased rate of loss roughly after 1995, but with a high spatiotemporal variability. We suggest that those HK MB averages during the 90s should be regarded with caution given the scarcity of MB data and our new evidences that the Chhota Shigri Glacier (and probably the surrounding glaciers of the whole Lahaul and Spiti region) had a balanced mass budget during 1988-1999. Our study indicates, in agreement with these compilations, more negative balance since, perhaps, the late 1990s.

The paucity of MB observations available to compute the HK MB averages gives a large weight to individual MB measurements, some of them being questionable. Indeed, due to a difficult access to the accumulation areas, it seems that some glaciers are probably surveyed only in their lower part (which is not always clearly mentioned in sources), making the glacier-wide MB biased negatively. This may be the case of the Hamtah Glacier, for which the MBs are strongly negative (Fig. 7). The field MBs are not consistent with our space-borne measurements. For this glacier, we measured a geodetic MB of $-0.45 \pm 0.16 \mathrm{~m}$ w.e. $\mathrm{yr}^{-1}$ during 1999-2011 (Fig. 5), whereas the glaciological MB was $-1.46 \mathrm{~m}$ w.e. $\mathrm{yr}^{-1}$ during 2000-2009 (Table 1). Consequently, some of the ground-based observational data and thus the HK MB averages, are probably biased toward negative MB. 


\subsection{Regional representativeness of Chhota Shigri Glacier MB}

Our remote sensing analysis suggests similar mass balances for the Chhota Shigri Glacier and for $2110 \mathrm{~km}^{2}$ of surrounding glaciers in the Lahaul and Spiti region during 1999-2011. A crucial question is to determine whether the MB of the Chhota Shigri Glacier remains similar to the MB of the whole region for other periods. If it is the case, it would mean that the whole region had a stable or slightly positive mass budget during the 1990s. This question, relative to the representativeness of a single glacier has not been examined yet in the Himalaya but has been thoroughly studied in other regions with numerous mass balance measurements. This hypothesis is supported by a growing body of literature suggesting similar temporal variability in glacier MB within a given mountain range (e.g. Huss et al., 2010; Vincent et al., 2004; Rasmussen, 2004; Soruco et al., 2009). Rasmussen (2004) found a strong correlation between the mass balance of 12 Scandinavian glaciers and concluded that measurements on one well-chosen glacier (Hardangerjøkulen) provides a good estimate of the average mass balance of other glaciers. Using fifty years of annual mass balance data for several glaciers in the Alps, Vincent et al. (2004) showed that mass balance fluctuations are very similar. The European Alps have a similar glaciarized area as the Lahaul and Spiti region $\left(\sim 2100 \mathrm{~km}^{2}\right)$ and is unique by its high density of mass balance measurements. Huss (2012) took advantage of this high field-data concentration (i) to extrapolate observed mass balances to the whole Alps and (ii) to discuss the representativeness of existing long-term monitoring programs. He concluded that two glaciers, Vernagtgletscher and Sonnblickgletscher (both in Austria), appear to be suitable index glaciers for the Alpine mass balance, with a $>50 \mathrm{yr}$ mean mass balance only $0.05 \mathrm{~m}$ w.e. less negative than the region-wide mass balance. Using the data from Huss (2012), we computed the differences between the decadal mass balance for Vernagtgletscher, Sonnblickgletscher, and the whole Alpine mass balance. The standard deviation of the difference is $\pm 0.20 \mathrm{~m}$ w.e. for Vernagtgletscher ( $\mathrm{N}=5$ decades) and $\pm 0.09 \mathrm{~m}$ w.e. for Sonnblickgletscher ( $\mathrm{N}=6$ decades). This simple analysis in a well-surveyed mountain range provides a first-order indication of the error that one would commit by assuming a single glacier to be representative of a whole region for a specific decade where no regional measurements are available. In conclusion, given that the MB of Chhota Shigri glacier is only $0.05 \mathrm{~m}$ w.e. $\mathrm{yr}^{-1}$ less negative than the regional MB during 1999-2011 (Table 4), we propose that the mass balance for Spiti and Lahaul did not deviate by more than $\pm 0.25 \mathrm{~m}$ w.e. (sum of $0.20 \mathrm{~m}$ w.e. and $0.05 \mathrm{~m}$ w.e.) from the one of the Chhota Shigri Glacier and thus, was also close to 0 during the 1990s.
However, we stress that the representativeness of the Chhota Shigri Glacier cannot be extended to the rest of the western Himalaya. Western Himalaya $\left(\sim 9000 \mathrm{~km}^{2}\right.$ of glaciers) is much larger than the Lahaul and Spiti region alone and characterized by, from west to east, decreasing influence of the midlatitude westerlies and increasing influence of the Indian monsoon (Bookhagen and Burbank, 2010), leading to distinct accumulation regimes on glaciers depending on their location. Given that the climatic sensitivity of glacier MB depends mainly on precipitation seasonality (Fujita, 2008), the response of these glaciers to climate change could be very different throughout the western Himalaya and could explain part of the spatial and temporal variability observed in Fig. 7. Another cause of this heterogeneous pattern could be related to the debris cover of these glaciers. The Chhota Shigri Glacier is almost free of debris, whereas some of the surveyed glaciers are partially debriscovered. Thick debris cover reduces melting by shielding and insulating glacier surfaces (e.g. Kayastha et al., 2000). Many recent studies highlight the importance of debris cover in the contrasted glacier response to climate change (e.g. Bolch et al., 2011; Fujita and Nuimura, 2011; Gardelle et al., 2012a; Kääb et al., 2012; Nuimura et al., 2012; Scherler et al., 2011). Given that thick debris cover is common in the Himalayas, it is very difficult to determine the sensitivity of Himalayan glaciers to climate change. It results that the paucity of data do not allow us to draw a consistent picture of mass change of the western Himalayan glaciers over the last $30 \mathrm{yr}$.

\section{Conclusions}

The Chhota Shigri Glacier slightly gained mass or was near equilibrium in the 1990s before entering a period of mass loss since, at the latest, 1999. A similar behavior may have been experienced by other glaciers in the Lahaul and Spiti region $\left(2110 \mathrm{~km}^{2}\right.$ of glaciarized area). A positive or nearzero MB in the 1990s deviates from the most recent compilation (Bolch et al., 2012) of MB data in the Himalayan range that indicates ice wastage over the past five decades with an increased rate of loss roughly after 1995, but with a high spatiotemporal variability and nearly inexistent MB measurements in the 1990s for the western Himalayas. In agreement with this compilation, our study confirms more negative mass budgets since, at the latest, the late 1990s. The meteorological drivers of these balanced or slightly positive cumulative MBs between 1988 and 1999 will be analysed in a further study. As mentioned in numerous studies (e.g. Oerlemans, 2001) and especially for Himalayan glaciers with heavily debris-covered tongues (Bolch et al., 2012), changes in glacier length and area are indirect indicators of climate change. Although our new measurements help to improve our knowledge of the glacier MB for a region (Lahaul and Spiti) during the last two decades, we stress that these MB may not apply to the whole western Himalaya. Together with other recent studies (e.g. Bolch et al., 2012; Gardelle et al., 


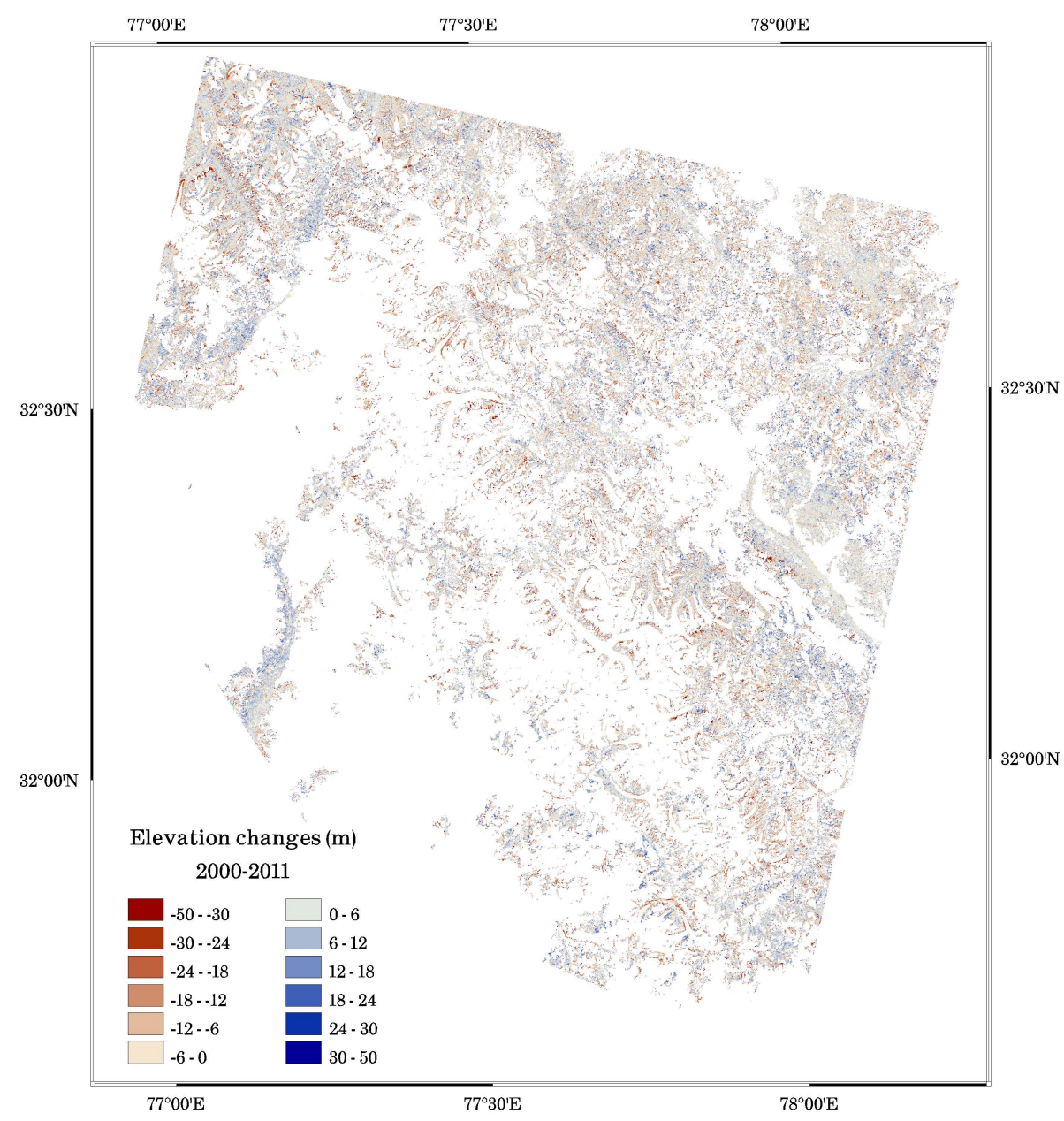

Fig. A1. Map of elevation changes between February 2000 and October 2011 off glaciers in the Lahaul and Spiti region.

2012a; Kääb et al., 2012), this study contributes in drawing a complex picture of the Karakoram and Himalayan glacier response to recent climate change.

Consequently, and as now commonly accepted, there is an urgent need to maintain and develop long-term groundbased surface MB observations on benchmark glaciers in the Himalayas, covered or not by debris. Additionally, remote sensing analysis (based on aerial photographs or satellite images) must be used and improved to calibrate the cumulative MB of these glaciers, extend the observations to large areas and test the representativeness of glaciers monitored in the field. Geodetic MB covering periods of 4 to 5 decades can also be inferred from satellite spy stereo-imagery acquired in the 1960s and 1970s (Bolch et al., 2011) and should, when possible, be estimated for other regions of the Himalayas.
Acknowledgements. This work has been supported by the IFCPAR/CEFIPRA under project no. 3900-W1 and by the French GLACIOCLIM observation service as well as the Department of Science and Technology (DST) and the Space Application Centre of the Government of India. The French National Research Agency through ANR-09-CEP-005-01/PAPRIKA provided DGPS devices to perform field measurements. We thank our field assistant Mr. B. B. Adhikari and the porters who were involved in successive field trips, Jawaharlal Nehru University for providing all the facilities to carry out this work, P. Chevallier for providing the map and A. Racoviteanu for commenting this manuscript. E. Berthier acknowledges support from the French Space Agency (CNES) and from the Programme National de Télédétection Spatiale (PNTS). We thank Matthias Huss for sharing the data from his mass balance reconstruction in the European Alps. We are grateful to T. Bolch and an anonymous reviewer whose comments greatly improved the quality of the manuscript.

Edited by: A. Kääb 


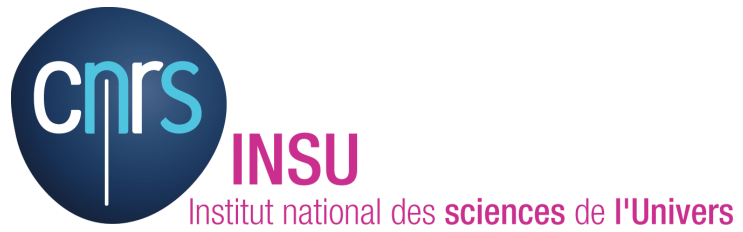

The publication of this article is financed by CNRS-INSU.

\section{References}

Azam, M. F., Wagnon, P., Ramanathan, A., Vincent, C., Sharma, P., Arnaud, Y., Linda, A., Pottakkal, J., Chevallier, P., Singh, V. B., and Berthier, E.: From balance to imbalance: a shift in the dynamic behaviour of Chhota Shigri Glacier (Western Himalaya, India), J. Glaciol., 58, 315-324, doi:10.3189/2012JoG11J123, 2012.

Berthier, E., Arnaud, Y., Vincent, C., and Remy, F.: Biases of SRTM in high-mountain areas: Implications for the monitoring of glacier volume changes, Geophys. Res. Lett., 33, L08502, doi:10.1029/2006GL025862, 2006.

Berthier, E., Arnaud, Y., Kumar, R., Ahmad, S., Wagnon, P., and Chevallier, P.: Remote sensing estimates of glacier mass balances in the Himachal Pradesh (Western Himalaya, India), Remote Sens. Environ., 108, 327-338, doi:10.1016/j.rse.2006.11.017, 2007.

Berthier, E., Scambos, T. A., and Shuman, C. A.: Mass loss of Larsen B tributary glaciers (Antarctic Peninsula) unabated since 2002, Geophys. Res. Lett., 39, doi:10.1029/2012GL051755, 2012.

Berthier, E. and Vincent, C.: Relative contribution of surface mass balance and ice flux changes to the accelerated thinning of the Mer de Glace (Alps) over 1979-2008, J. Glaciol., 58, 501-512, 2012.

Bhambri, R., Bolch, T., Chaujar, R. K., and Kulshreshtha, S. C.: Glacier changes in the Garhwal Himalaya, India, from 1968 to 2006 based on remote sensing, J. Glaciol., 57, 543-556, 2011.

Bolch, T., Kulkarni, A., Kääb, A., Huggel, C., Paul, F., Cogley, J. G., Frey, H., Kargel, J. S., Fujita, K., Scheel, M., Bajracharya, S., and Stoffel, M.: The State and Fate of Himalayan Glaciers, Science, 336, 310-314, 2012.

Bolch, T., Pieczonka, T., and Benn, D. I.: Multi-decadal mass loss of glaciers in the Everest area (Nepal Himalaya) derived from stereo imagery, The Cryosphere, 5, 349-358, doi:10.5194/tc-5349-2011, 2011.

Bookhagen, B. and Burbank, D. W.: Toward a complete Himalayan hydrological budget: Spatiotemporal distribution of snowmelt and rainfall and their impact on river discharge, J. Geophys. Res., 115, F03019, doi:10.1029/2009JF001426, 2010.

Brock, B. W., Willis, I. C., and Sharp, M. J.: Measurements and parameterization of albedo variations at Haut Glacier d'Arolla, Switzerland, J. Glaciol., 46, 675-688, 2000.

Cogley, J. G.: Geodetic and direct mass-balance measurements: comparison and joint analysis, Ann. Glaciol., 50, 96-100, 2009.

Cogley, J. G.: Present and future states of Himalaya and Karakoram glaciers, Ann. Glaciol., 52, 2011.

Cuffey, K. M. and Paterson, W. S. B.: The physics of glaciers, 4 Edn., Academic Press Inc, Amsterdam, 2010.
Dobhal, D. P.: Inventory of Himachal glaciers and glaciological studies of Chhota Shigri glacier, Himachal Pradesh: a case history, Ph.D. thesis of the Garhwal University, Srinagar, 1992.

Dobhal, D. P., Kumar S., and Mundepi A. K.: Morphology and glacier dynamics studies in monsoon-arid transition zone: an example from Chhota Shigri glacier, Himachal Himalaya, India. Current Sci., 68, 936-944, 1995.

Dobhal, D. P., Gergan J. T., and Thayyen, R. J.: Mass balance studies of the Dokriani Glacier from 1992 to 2000, Garhwal Himalaya, India, Bull. Glaciol. Res., 25, 9-17, 2008.

Dyurgerov, M. B. and Meier, M. F.: Glaciers and the Changing Earth System: a 2004 Snapshot, INSTAAR, Boulder, 117 pp., 2005.

Fujita, K.: Effect of precipitation seasonality on climatic sensitivity of glacier mass balance, Earth Planet. Sci. Lett., 276, 14-19, doi:10.1016/j.epsl.2008.08.028, 2008.

Fujita, K. and Nuimura, T.: Spatially heterogeneous wastage of Himalayan glaciers, Proc. Natl. Acad. Sci., 108, 14011-14014, 2011.

Gardelle, J., Berthier, E., and Arnaud, Y.: Slight mass gain of Karakorum glaciers in the early 21 st century, Nat. Geosci., 5, 322-325, doi:10.1038/ngeo1450, 2012a.

Gardelle, J., Berthier, E., and Arnaud, Y.: Impact of resolution and radar penetration on glacier elevation changes computed from multi-temporal DEMs, J. Glaciol., 58, 419-422, 2012 b.

Gautam, C. K. and Mukherjee B. P.: Mass-balance vis-à-vis snout position of Tipra bank glacier District Chamoli, Uttar Pradesh, Proc. Natl. Meet Himalayan Glaciol, 5-6 June 1989, 141-148, 1989.

Geological Survey of India (GSI): Glaciological studies on Dunagiri Glacier, district Chamoli (Field Seasons 1983-84 to 199192), Final Report 1992, 5-9, 1992.

Geological Survey of India (GSI): Chapter 8, Annual Report 19911992, 175-176, 1992.

Geological Survey of India (GSI): Chapter 8, Annual Report 2010 2011, 69-70, 2011.

Huss M.: Extrapolating glacier mass balance to the mountain-range scale: the European Alps 1900-2100, The Cryosphere, 6, 713727, doi:10.5194/tc-6-713-2012, 2012.

Huss, M., Hock, R., Bauder, A., and Funk, M.: 100-year mass changes in the Swiss Alps linked to the Atlantic Multidecadal Oscillation, Geophys. Res. Lett., 37, L10501, doi:10.1029/2010GL042616, 2010.

Immerzeel, W. W., van Beek, L. P. H., and Bierkens, M. F. P.: Climate Change Will Affect the Asian Water Towers, Science, 328, 1382-1385, 2010.

Kääb, A., Berthier, E., Nuth, C., Gardelle, J., and Arnaud, Y.: Contrasting patterns of early 21 st century glacier mass change in the Himalaya, Nature, 488, 495-498, doi:10.1038/nature11324, 2012.

Kargel, J. S., Cogley, J. G., Leonard, G. J., Haritashya, U., and Byers, A.: Himalayan glaciers: The big picture is a montage, Proc. Natl. Acad. Sci., 108, 14709-14710, 2011.

Kaser, G., Großhauser, M., and Marzeion, B.: Contribution potential of glaciers to water availability in different climate regimes, Proc. Natl. Acad. Sci., 107, 20223-20227, doi:10.1073/pnas.1008162107, 2010.

Kayastha, R. B., Takeuchi Y., Nakawo M., and Ageta Y.: Practical prediction of ice melting beneath various thickness of debris cover on Khumbu glacier, Nepal, using a positive degree-day fac- 
tor, IAHS Publ., 264, 71-82, 2000.

Korona, J., Berthier, E., Bernard, M., Remy, F. and Thouvenot, E.: SPIRIT. SPOT 5 stereoscopic survey of Polar Ice: Reference Images and Topographies during the fourth International Polar Year (2007-2009), ISPRS J. Photogr. Remote Sens., 64, 204 212, doi:10.1016/j.isprsjprs.2008.10.005, 2009.

Koul, M. N. and Ganjoo R. K.: Impact of inter- and intra-annual variation in weather parameters on mass balance and equilibrium line altitude of Naradu Glacier (Himachal Pradesh), NW Himalaya, India, Clim. Change, 99, 119-139, doi:10.1007/s10584009-9660-9, 2010.

Kumar, S.: Chhota Shigri Glacier: its kinematic effects over the valley environment, in the northwest Himalaya, Current Sci., 77, 594-598, 1999.

Nijampurkar, V. N. and Rao D. K.: Accumulation and flow rates of ice on Chhota Shigri Glacier, central Himalaya, using radioactive and stable isotopes, J. Glaciol., 38, 43-50, 1992.

Nuimura, T., Fujita, K., Yamaguchi, S., and Sharma, R. R.: Elevation changes of glaciers revealed by multitemporal digital elevation models calibrated by GPS survey in the Khumbu region, Nepal Himalaya, 1992-2008, J. Glaciol., 58, 648-656, doi:10.3189/2012JoG11J061, 2012.

Nuth, C., and Kääb, A.: Co-registration and bias corrections of satellite elevation data sets for quantifying glacier thickness change, The Cryosphere, 5, 271-290, doi:10.5194/tcd-4-20132010, 2011.

Oerlemans, J.: Glaciers and climate change, edited by: Oerlemans, J., A. A. Balkema Publishers, Rotterdam, 2001.

Ohmura, A.: Observed Mass Balance of Mountain Glaciers and Greenland Ice Sheet in the 20th Century and the Present Trends, Surv. Geophys., 32, 537-554, 2011.

Rabus, B., Eineder, M., Roth, A., and Bamler, R.: The shuttle radar topography mission - a new class of digital elevation models acquired by spaceborne radar, ISPRS J. Photogr. Remote Sens., 57, 241-262, 2003.

Racoviteanu, A., Paul, F., Raup, B., Khalsa, S. J. S., and Armstrong, R.: Challenges and recommendations in mapping of glacier parameters from space: results of the 2008 Global Land Ice Measurements from Space (GLIMS) workshop, Boulder, Colorado, USA, Ann. Glaciol., 50, 53-69, 2009.

Raina, V. K.: Himalayan glaciers, A state-of-art review of glacial studies, glacial retreat and climate change, Ministry of Environment and Forests, India, http://go.nature.com/pLgJ6D, 2009.
Raina, V. K., Kaul, M. K., and Singh, S.: Mass-balance studies of Gara Glacier, J. Glaciol., 18, 415-423, 1977.

Rasmussen, L. A.: Altitude variation of glacier mass balance in Scandinavia, Geophys. Res. Lett., 31, L13401, doi:10.1029/2004GL020273, 2004.

Scherler, D., Bookhagen, B. and Strecker, M. R.: Spatially variable response of Himalayan glaciers to climate change affected by debris cover, Nat. Geosci., 4, 156-159, 2011.

Schwitter, M. P. and Raymond, C. F.: Changes in the Longitudinal Profiles of Glaciers during Advance and Retreat, J. Glaciol., 39, 582-590, 1993.

Shekhar, M. S., Chand, H., Kumar, S., Srinivasan, K., and Ganju, A.: Climate-change studies in the western Himalaya, Ann. Glaciol., 51, 105-112, 2010.

Shrivastava, D., Sangewar C. V., Kaul, M. K., and Jamwal, K. S.: Mass balance of Rulung Glacier- a Trans-Himalayan glacier, Indus basin, Ladak. Proc. Symp. Snow, Ice and Glacier, March 1999, Geol. Surv. India, Special Publication, 53, 41-46, 2001.

Soruco, A., Vincent, C., Francou, B., and Gonzalez, J. F.: Glacier decline between 1963 and 2006 in the Cordillera Real, Bolivia, Geophys. Res. Lett., 36, L03502, doi:10.1029/2008GL036238, 2009.

Thayyen, R. J. and Gergan, J. T.: Role of glaciers in watershed hydrology: a preliminary study of a "Himalayan catchment", The Cryosphere, 4, 115-128, 2010, http://www.the-cryosphere-discuss.net/4/115/2010/.

Vincent, C., Kappenberger, G., Valla, F., Bauder, A., Funk, M., and Le Meur, E.: Ice ablation as evidence of climate change in the Alps over the 20th century, J. Geophys. Res., 109, D10, D10104, doi:10.1029/2003JD003857, 2004.

Wagnon, P., Linda, A., Arnaud, Y., Kumar, R., Sharma, P., Vincent, C., Pottakkal, J. G., Berthier, E., Ramanathan, A., Hasnain, S. I and Chevallier, P.: Four years of mass balance on Chhota Shigri Glacier, Himachal Pradesh, India, a new benchmark glacier in the western Himalaya, J. Glaciol., 53, 603-611, 2007.

WGMS: Glacier Mass Balance Bulletin \#11 (2008-2009), edited by: Zemp, M., Nussbaumer, S. U., GartnerRoer, I., Hoelzle, M., Paul, F. and Haeberli, W., ICSU(WDS)/IUGG(IACS)/UNEP/UNESCO/WMO, World Glacier Monitoring Service, Zurich, 20 Switzerland, 102 pp., 2011. 